\section{The Merits of Alcohol as a Skin Degerming Agent}

\section{To the Editor:}

In the May 1984 issue of Infection Control, there are Letters to the Editor by Nyström and by Larson ${ }^{1.2}$ concerning the use of alcohol as a skin degerming agent. The main problem is that alcohol is relatively inexpensive and therefore there has been very little effort on the part of industry to sell this product.

Alcohol foam is available in this country, and special devices are available for mounting the containers on the wall of patient rooms, cubicles, and even on mobile carts. We have used the foam extensively and, in fact, it is found by every bedside in our hospital. Physicians have these in their offices and at every laboratory bench in our research facility.

The material does not dry the skin nor is it antigenic. I would recommend its use not only in the health care institutions, but also for patients with diarrhea or with respiratory infections. Properly placed it is useful for patient visitors, housekeeping personnel, and physicians and nurses.

\section{REFERENCES}

I. Nyström B: Scandinavian experience differs, letter to the editor. Infect Control 1984: 5:211.

2. Larson E: Scandinavian experience differs, letter to the editor reply. Infect Control 1984; 5:211.

3. Beck WC: Alcohol foam for hand disinfection AORN J 1980; p 1087.

William C. Beck, MD, FACS President Emeritus Donald Guthrie Foundation for Medical Research

Sayre, Pennsylvania

Dr. Nyström offers his reply to Dr. Beck's letter.

Is it not a sad world if an effective and useful preparation is little mar- keted and used because it is inexpensive?

As stated in my earlier Letter to the Editor, ${ }^{1}$ in Sweden we use $70 \%$ ethanol with $2 \%$ glycerol for staff hand disinfection. We find it useful and acceptable. Various dispensers are used with the common property of preventing significant evaporation.

It has recently been demonstrated that a rub with $0.5 \mathrm{ml} 70 \%$ isopropanol that is allowed to air dry on the hands prevents transfer of microorganisms from them at least as efficiently as a 30-60s wash with soap and water. ${ }^{2}$ However, a 30-60s duration of hand wash is unrealistic. A mean duration of handwashing for health care personnel of $8.6 \mathrm{~s}$ has recently been reported. ${ }^{3}$ This figure is in agreement with our experiences. Seventy percent ethanol is slightly less effective than $70 \%$ isopropanol. We still prefer the ethanol because the smell of isopropanol is considered unacceptably disagreeable by many.

The alcohol foam recommended by Beck is not commercially available in our country, and we have no experience of it. It is originally described ${ }^{4}$ as based on $50 \%$ ethanol. Can this be comparable in effect to either $70 \%$ ethanol or $70 \%$ isopropanol? I assume that it is more expensive than a simple mixture of alcohol in liquid form and glycerol.

\section{REFERENCES}

I. Nyström B: Scandinavian experience differs, letter to the editor. Infect Control 1984; 5:211.

2. Mackintosh CA, Hoffman PN: An extended model for transfer of microorganisms via the hands: Differences between organisms and the effect of alcohol disinfection. $J$ Hyg 1984; 92:345-355.

3. Quraishi ZQ, McGuckin M, Blais FX: Duration of handwashing in intensive care units: A descriptive study. Am J Infect Control 1984; 12:83-87.

4. Dineen P, Hildick-Smith G: Antiseptic care of the hands, in Maibach HI, Hildick-Smith G: Skin Bacteria and Their Role in Infection. New York, McGrawHill Book Co, 1965, pp 291-309.

Bertil Nyström, MD

Department of Clinical Microbiology Huddinge University Hospital Stockholm, Sweden

\section{Air Hand Dryer or Paper Towel Dispensers?}

An air hand dryer has been requested to replace paper towel dispensers, for clean and dirty utility rooms on patient units in our hospital. The doors to these rooms are supposed to be closed at all times, but many times they are found propped open. Please comment on this from an infection standpoint.

Nancy Byrne, RN OR, CSR Supervisor, Infection Control Nurse

Inter-Community Memorial Hospital Newfane, New York

Sue Crow, RN, MSN, was asked to respond to Ms. Byrne's query.

I am not aware of studies that compare drying hands with a paper towel versus an air dryer. It is interesting that several manufacturers of air hand dryers I contacted did not recommend them for general use in hospitals but only in public restrooms.

Consider the following:

1. It takes longer to dry hands using an air dryer-most manufacturers set the timer for 30 seconds. Will hospital personnel take this time to assure their hands are completely dry? I doubt it; they probably will end up drying them on the seat of their pants. It seems reasonable that wet hands could harbor more microorganisms and therefore be a greater risk factor.

2. Without the paper towel, there would be no way to turn off the faucet without contaminating your hands. Not all hospital sinks have foot or knee controls.

3. The temperature of an air dryer usually reaches $164^{\circ} \mathrm{F}$ in seven seconds. This method does not offer any antiseptic advantages. 